\title{
Simplified and Precise Design of Crossflow Turbine Power Transmission Components
}

\author{
Williams S. Ebhota, Pavel Y. Tabakov
}

\begin{abstract}
Despite the merits of small hydropower (SHP), coupled with the perennial inadequate and unreliable electricity supply in SSA, the huge SHP potential in the region is hugely untapped. This is largely attributed to the lack of adequate technical components for the development of SHP turbines, which are: technical personnel, and production facilities in the region. The hydraulic power possessed by flowing water in SHP resources can be harnessed and transformed into usable electrical energy via the deployment of a hydro turbine plant. Commonly used hydro turbines include crossflow (CFT), Pelton, Turgo, and Francis turbines. Amongst these turbines, CFT is mostly applied in low head sites and has efficiency ranging from 70-85\%. The CFT power transmission subsystem is considered vital to its performance; the shaft, which transmits the generated motion to drive the alternator, is the most critical part of the CFT transmission subsystem and it requires careful design and production processes. This study centres on the development of a simplified systematic design process for power transmission shaft, pulley, and belt, to facilitate CFT power generation efficiency. .Further, the study is geared towards boosting CFT technology capacity domestically for the benefit of local production. The hydrological properties of the Ayiba SHP site in Osun state, Nigeria, were adopted for this work as a case study. The head and power for this resource are $11.8 \mathrm{~m}$ and $122.4 \mathrm{~kW}$, respectively, and are served as the fundamental parameters for the design of the power transmission subsystem. The design computation shows that a shaft of diameter $65 \mathrm{~mm}$ and a D-type of V-belt with a corresponding pulley will be required to transmit the generated turbine power to the alternator. A 3-D model was created based on the design values and this was used to validate the integrity of the shaft by static stimulation. The simulation result, which is based on von Mises was satisfactory as the highest stress obtained in the shaft was $205 \mathrm{~N} / \mathrm{mm} 2$; resulting in a 2.6 factor of safety.

Keywords: Small hydropower; Hydro turbine; Crossflow turbine; Crossflow shaft; Crossflow turbine transmission system; $V$-belt and pulley selection
\end{abstract}

\section{INTRODUCTION}

\section{$T$} here is numerous untapped small hydropower (SHP) resources in developing regions, especially, sub-Saharan Africa SSA. Decades of exploitation of SHP resources for energy, the use of a turbine, has proven to be reliable in providing a clean energy source to meet electricity demand.

Manuscript received on January 04, 2020.

Revised Manuscript received on February 05, 2021.

Manuscript published on February 28, 2021

* Correspondence Author

Williams S, Ebhota*, Department of Mechanical Engineering, Institute for Systems Science, Durban University of Technology, Durban, South Africa. Email: ebhotawilliams1@gmail.com

Pavel Y. Tabakov, Department of Mechanical Engineering, Institute for Systems Science, Durban University of Technology, Durban, South Africa. Email: pashat@dut.ac.za

(C) The Authors. Published by Blue Eyes Intelligence Engineering and Sciences Publication (BEIESP). This is an open access article under the CC BY-NC-ND license (http://creativecommons.org/licenses/by-nc-nd/4.0/)
This energy technology is also considered for its design and maintenance simplicity, low cost, and generation of electricity with reduced $\mathrm{CO}_{2}$ emission. The vast SHP potential in the region is hugely untapped despite these advantages coupled with the perennial inadequate and unreliable electricity supply in SSA. This is largely attributed to the lack of adequate technical components for the development of SHP turbines, which include both technical personnel and production facilities in the region [1, 2]. Sub-Saharan Africa has the highest percentage of the global population without access to electricity and these people mostly dwell in the rural areas. This situation has been projected to linger even after 2030. The region is endowed with SHP resources, and the SHP electrification scheme has been described by many studies as most the effective rural and standalone electrification system [3], yet several people in the rural area are without electricity, this scenario perplexes the authors. The total SHP potential in SSA is estimated at 3,421 MW [4]; this can change the disheartening narrative of the region's power situation if adequately harnessed [5-7]. The Republic of China has demonstrated this and utilized SHP to generate 19,000 MW of electricity from 43,000 SHP sites. The situation is different in SSA, as the development of SHP technologies is grossly inadequate to support the power sector substantively, despite that studies have shown that the region has a huge presence of feasible SHP resources [4, 8].

The development of SHP in SSA has been very slow due to several factors, which include inadequate technical capacity, as summed up in a study [2]. The advantage of SHP technologies over the large hydropower plants has been stretched further by the modern energy requirements and energy emerging technologies, such as off-grid, energy mix system, sustainability, and environmental friendliness. Other merits of SHP deployment include a robust simple technology that can last for about 50 years or more, with minimal maintenance [9]; a simple network and transmission system; and clean electricity. The utilisation of adequate SHP for power generation will reduce the amount of fossil fuel consumption and pollution; since power generation contributes the highest $\mathrm{CO}_{2}$ emission (26\%) [10, 11]. Generally, the cost of power generation from hydropower system is comparatively very low, between $0.02 / \mathrm{kWh}$ and $0.05 / \mathrm{kWh}$ USD [12, 13]. The hydraulic power possessed by flowing water in these SHP resources can be harnessed and transformed into usable electrical energy via the deployment of a hydro turbine plant.

Published By:

Blue Eyes Intelligence Engineering DOI:10.35940/ijeat.C2136.0210321 
The hydro turbine technology has evolved over the years into different types, in tandem with site properties.

The commonly used hydro turbines include crossflow (CFT), Pelton, Turgo, and Francis turbines. Amongst these turbines, CFT is mostly applied in low head sites and has efficiency in the range of 70-85\%. Many studies have identified these same shortcomings hindering the development of SHP in developing countries, and have strived to bridge this gap through different design and fabrication models [14-16]. However, this study observes that several of the existing studies lack clarity, simplicity, calculation reliability, and details. Hence, this study deals with the power transmission subsystem of CFT, comprising power transmission shaft, belt, and pulley for low head application. A 3-D model of the transmission shaft will be created based on the dimensions obtained from the design computation and used for shaft reliability tests through static simulation. This study is designed to serve as a dependable manual for the design and fabrication of CFT power transmission components.

\section{METHODOLOGY}

The basic design and selection parameters of CFT transmission components will be based on hydrological information of an SHP site, Ayiba, located in Osun State, Nigeria, obtained from two studies [17, 18]. This information is presented in Table 1 . The existing theoretical and empirical relations, based on the established optimization benchmarks, will be used for the design of the different power transmission components of the CFT. The 3-D models will be created using Solidworks design software, and the model will be used to carry out stress analysis simulations. The integrity and robustness of the shaft will be determined from the simulation results.

Table 1: Ayiba SHP site information $[17,18]$

\begin{tabular}{cccc}
\hline $\begin{array}{c}\text { Name } \\
\text { of site }\end{array}$ & $\begin{array}{c}\text { Average } \\
\text { water head } \\
(\mathbf{m})\end{array}$ & $\begin{array}{c}\text { Theoretical } \\
\text { plant generating } \\
\text { capacity } \mathbf{~ k W}\end{array}$ & $\begin{array}{c}\text { Theoretical } \\
\text { flow rate }\left(\mathbf{m}^{\mathbf{3}} / \mathbf{s}\right) \\
\left(\boldsymbol{\eta}_{\mathbf{t}}=\mathbf{7 5 \%}\right)\end{array}$ \\
\hline Ayiba & 11.58 & 122.4 & 1.4093 \\
\hline
\end{tabular}

\section{CROSSFLOW TURBINE POWER TRANSMISSION COMPONENTS}

The Crossflow turbine belongs to the same family as the Pelton turbine; the impulse turbine class, which is majorly composed of three components, the runner, nozzle, and generator (alternator). The nozzle conveys a calculated amount of water to the runner at a certain angle. The runner, a cylindrical rotor is responsible for the conversion of the hydraulic energy contained in a jet or flowing water into a rotary motion. This rotary motion is transmitted via shaft, pulley, and belt to the generator for the production of electricity or driving a mechanical device. The simplicity of CFT design, fabrication, and maintenance, as well as a wide range of operational head and discharge, make it the choice for local SHP plant development. The operational range of head and discharge is from 4 to $200 \mathrm{~m}$ and 0.04 to $5 \mathrm{~m}^{3} / \mathrm{s}$, respectively. The transmission subsystem of CFT consists of rotating machine elements responsible for the transmission of the hydraulic power harnessed by the runner to the generator (alternator) to generate electricity. The transmission components of CFT, such as the shaft, crank, sprockets, flywheel, pulleys, and belts, have not been given adequate focus in the design process of a CFT system. Usually, other transmission elements are mounted on a shaft, with a circular cross-section. They are always subjected to a torsional moment or torque during the process of power transmission at a given rotational speed. Hence, it is necessary to determine the shaft diameter from the maximum torque that can be transferred through these components without failure, especially the shaft. Otherwise, the functionality of the CFT will be affected, because of component failure.

\section{A. Design inputs of CFT transmission system}

The design of the shaft and other parts that make up the CFT power transmission subsystem requires the input of basic parameters, which include hydrological information of the SHP potential site. This information is contained in Table 2.

Table 2: Site hydrological information and other basic turbine design parameters

\begin{tabular}{|c|c|c|c|c|c|}
\hline $\begin{array}{l}\text { Paramete } \\
\text { r }\end{array}$ & $\begin{array}{l}\text { Magnitud } \\
\text { e }\end{array}$ & Unit & $\begin{array}{l}\text { Paramete } \\
\text { r }\end{array}$ & $\begin{array}{l}\text { Magnitud } \\
\text { e }\end{array}$ & Unit \\
\hline $\begin{array}{l}\text { Net head } \\
\left(H_{n}\right)\end{array}$ & 11.58 & $\mathrm{M}$ & $\begin{array}{l}\text { Water } \\
\text { velocity } \\
\text { coefficient } \\
\text { (C) }\end{array}$ & 0.98 & \\
\hline $\begin{array}{l}\text { Flow rate } \\
(Q)\end{array}$ & 0.5 & $\mathrm{~m}^{3} / \mathrm{s}$ & $\begin{array}{l}\text { Attack } \\
\text { angle }(\alpha)\end{array}$ & 16 & $\circ$ \\
\hline $\begin{array}{l}\text { Turbine } \\
\text { power }\left(P_{t}\right)\end{array}$ & 122.4 & $\mathrm{~kW}$ & $\begin{array}{l}\text { Blade } \\
\text { roughness } \\
\text { coefficient } \\
(\Psi)\end{array}$ & 0.98 & $\begin{array}{l}\Psi \text { is the } \\
\text { and } C \text { is } \\
\text { the } \\
\text { Nozzle } \\
\text { roughness } \\
\text { coefficien } \\
\mathrm{t}(0.98)\end{array}$ \\
\hline $\begin{array}{l}\text { Generator } \\
\text { speed } \\
\left(\mathrm{N}_{\mathrm{G}}\right)\end{array}$ & 1500 & $\begin{array}{l}\mathrm{RP} \\
\mathrm{M}\end{array}$ & $\begin{array}{l}\text { Yield } \\
\text { strength } \\
\text { stress }\left(\sigma_{y}\right)\end{array}$ & 530 & $\mathrm{~N} / \mathrm{mm}^{2}$ \\
\hline $\begin{array}{l}\text { Turbine } \\
\text { speed }(N)\end{array}$ & 636 & $\begin{array}{l}\mathrm{RP} \\
\mathrm{M}\end{array}$ & $\begin{array}{l}\text { Shaft } \\
\text { material }\end{array}$ & AISI 1045 & $\begin{array}{l}\text { Yield } \\
\text { strength } \\
\text { is } 530 \\
\mathrm{MPa}\end{array}$ \\
\hline $\begin{array}{l}\text { Runner } \\
\text { diameter } \\
\left(D_{0}\right)\end{array}$ & 214 & $\mathrm{Mm}$ & $\begin{array}{l}\text { Factor of } \\
\text { safety }\end{array}$ & 2.6 & \\
\hline $\begin{array}{l}\text { Gravity } \\
(\mathrm{g})\end{array}$ & 9.81 & $\mathrm{~m} / \mathrm{s}^{2}$ & $\operatorname{Pi}(\pi)$ & 3.14 & \\
\hline $\begin{array}{l}\text { CFT } \\
\text { length }(L)\end{array}$ & & $\mathrm{M}$ & & & \\
\hline
\end{tabular}

\section{B. Design of CFT transmission shaft}

The shaft is the most critical amidst the rotating elements. It is usually circular in cross-section and is either solid or hollow. The CFT shaft is subjected to both torsion and bending loads and as such it requires strength and rigidity to transmit power under various loading and operating conditions, satisfactorily. However, an axial load is treated insignificantly because is comparatively very small in a rotating shaft, where axial, bending, and torsion stresses are present. For a constantly rotating shaft with torsion and bending, the torsion is steady and the bending stresses are completely reversed.

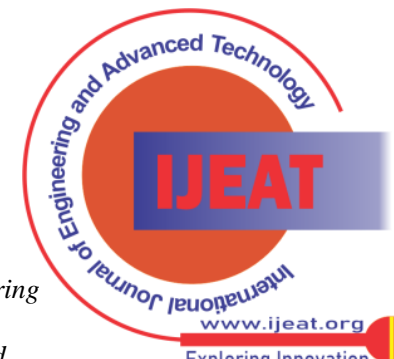




\section{Simplified and Precise Design of Crossflow Turbine Power Transmission Components}

The design of the CFT shaft is controlled by the maximum shear stress theory since they are usually made from ductile materials.
It is expected of the shaft to be large enough to avoid the deflection of more than 1 degree in a length 20 times its diameter. To compute the minimum shaft diameter to meet its functional needs, the equations in Table 3 will be required.

Table 3: Equations for shaft design

\begin{tabular}{|c|c|c|}
\hline \multicolumn{3}{|l|}{ Turbine shaft design and stress analysis } \\
\hline Turbine power $\left(P_{t}\right)$ in $\mathrm{W}$ & $P_{t}=T * \omega$ & \\
\hline Angular speed of the shaft $(\omega)$ in radians & $\omega=\frac{2 \pi N}{60}$ & \\
\hline Turbine shaft torque $(T)$ & $T=\frac{P_{t}}{\omega}$ & \\
\hline Maximum torque $\left(T_{\max }\right)$ in $\mathrm{N}-\mathrm{m}$ & $T_{\max }=1.25 * T$ & $\begin{array}{l}\text { Where } d \text { is the turbine shaft diameter; and } \tau \text { is the } \\
\text { shear stress of the shaft material (steel }=42 \mathrm{MPa} \text { ) }\end{array}$ \\
\hline Turbine shaft diameter $(d)$ in $\mathrm{mm}$ & $d=150 \sqrt{\frac{P_{t}}{N}}$ & Where $P_{t}$ is in $\mathrm{kW}$ \\
\hline $\begin{array}{l}\text { Power transmission to the alternator unit using } \\
\text { an open belt drive system }\end{array}$ & $\frac{N_{2}}{N_{G}}=\frac{d_{G}}{d_{s}}$ & $\begin{array}{l}\text { Where } d_{G} \text { and } d_{s} \text { are diameters of the driver and } \\
\text { driven pulleys, respectively, while } N_{G} \text { and } N \text { are speeds } \\
\text { of the driver and driven pulleys. }\end{array}$ \\
\hline The theoretical efficiency of the turbine $\left(\eta_{0}\right)$ & $\eta_{o}=\frac{\text { Shaft power }}{\text { Water power }}$ & \\
\hline
\end{tabular}

\section{Shaft material selection}

The dominant material used in industrial automation is a carbon steel of about 0.1 to 0.33 percent carbon content, accounting for almost $85 \%$ of all shafting. The most common types of carbon steel used are AISI 1045, 1060, 52100, and 1566. Its comparatively low cost, easy hardenability, and machinability make it attractive and outstanding for shaft fabrication. However, they fail at certain harsh working environmental conditions, such as high temperatures and rapidly corrosive media. The turbine shaft's working medium is water, and sometimes the water might be saline. In this scenario, alloy steels of silicon, copper, and aluminium, and stainless steel shafts that offer varying degrees of strength and corrosion resistance are considered and deployed for better performance. Stainless steel, which has a mix of low carbon content with chromium of not less than $12 \%$, is the best option, offering strength and high resistance to corrosion. Other alloying elements required to improve the required characteristics of stainless steel include aluminium, sulphur, nickel, manganese, silicon, niobium, molybdenum, copper, titanium, and selenium [19, 20]. The austenitic steel, 300, and 400 series stainless steel, such as 430,304 , and 316 , are the most commonly used for shaft [21]. They contain about $16 \%$ to $25 \%$ chromium, and they can contain nitrogen in solution, both of which contribute to their high corrosion resistance. In this study, AISI 1045 steel of yield Strength $530 \mathrm{~N} / \mathrm{mm}^{2}$ will be used and a minimum factor of safety (FOS) of 2.5 will be considered satisfactory. The detailed physical property of AISI 1045 steel is presented in Table 4.

Table 4: physical properties of AISI 1045 steel

\begin{tabular}{|l|l|}
\hline Name: & AISI 1045 Steel, cold drawn \\
\hline Model type & Linear Elastic Isotropic \\
\hline Yield strength & $5.3 \mathrm{e}^{+08 \mathrm{~N} / \mathrm{m}^{\wedge} 2}$ \\
\hline Tensile strength & $6.25 \mathrm{e}+08 \mathrm{~N} / \mathrm{m}^{\wedge} 2$ \\
\hline Elastic modulus & $2.05 \mathrm{e}+11 \mathrm{~N} / \mathrm{m}^{\wedge} 2$ \\
\hline Poisson's ratio & 0.29 \\
\hline Mass density & $7850 \mathrm{~kg} / \mathrm{m}^{\wedge} 3$ \\
\hline Shear modulus & $8 \mathrm{e}+10 \mathrm{~N} / \mathrm{m}^{\wedge} 2$ \\
\hline
\end{tabular}

\section{V-Belt selection}

A $\mathrm{V}$ belt is required to connect two pulleys in different sections of a machine, in which one serves as a driver and the other is driven. This arrangement is deployed to transmit motion or power from a section of the machine to another, due to the wedging action between the V-groove in the pulley and belt. The belts are an endless or looped strip of flexible material and are trapezoidal in cross-section. Both the V-belts and pulleys are frequently used due to the relatively cheap shafts compared to other means of power transmission. The V-belts perform optimally at speeds around $20 \mathrm{~m} / \mathrm{s}$ and the drive speed should not exceed $30 \mathrm{~m} / \mathrm{s}$. The generic geometry of a V-belt and pulley features and profile are shown in Fig 1.

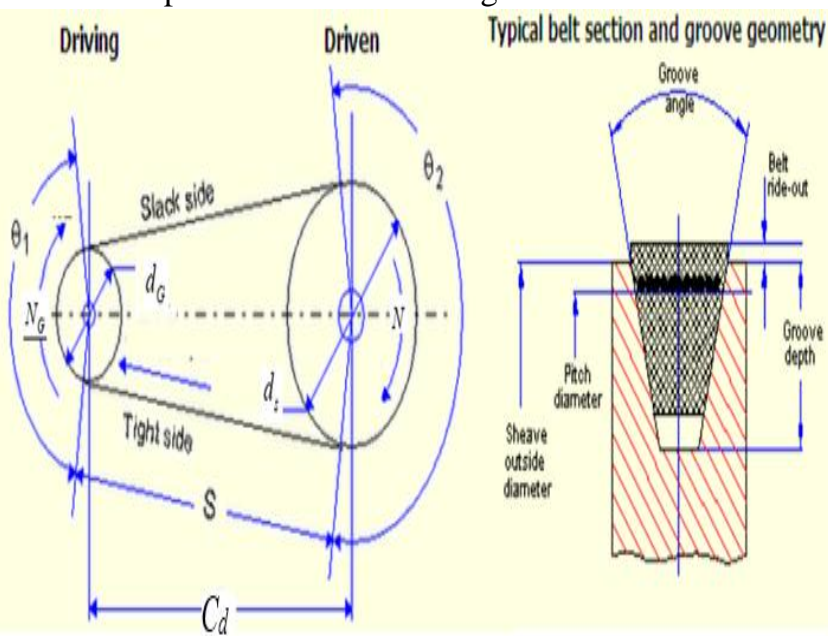

Fig 1: Transmission belt-pulley arrangement and Vbelt cross-sectional area

Published By:

Blue Eyes Intelligence Engineering

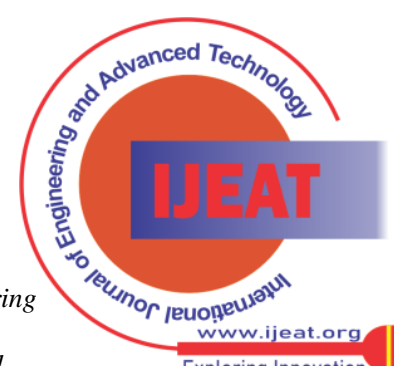


The required V-belt and pulley design expressions are presented in Table 5.

Table 5: V-belt and pulley design expressions

\begin{tabular}{|c|c|c|}
\hline \multicolumn{3}{|c|}{ V-belt and pulley design } \\
\hline $\begin{array}{l}\text { Transmission } \\
\text { ratio }\left(R_{\mathrm{t}}\right) R_{\mathrm{t}} \geq 1\end{array}$ & $R_{t}=\frac{N_{G}}{N}=\frac{d_{s p}}{d_{G p}}$ & $\begin{array}{l}\text { Where } d_{\mathrm{Gp}} \text { is pitch } \\
\text { diameter of the driving } \\
\text { pulley; and } d_{\mathrm{sp}} \text { is the pitch } \\
\text { diameter of the driven } \\
\text { pulley }\end{array}$ \\
\hline $\begin{array}{l}\text { Wrap angle or arc } \\
\text { of contact }(\theta)\end{array}$ & $\theta_{1}=\pi-2 \gamma ; \theta_{2}=$ & \\
\hline $\begin{array}{l}\text { The center } \\
\text { distance, } C_{\mathrm{d}}\end{array}$ & $d_{s}<C_{d}<3\left(d_{s}+\right.$ & \\
\hline $\begin{array}{l}\text { The belt length } \\
\left(L_{B}\right)\end{array}$ & 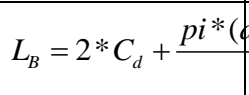 & \\
\hline Wrap angle $\left(\beta^{\circ}\right)$ & $\begin{array}{l}\beta=\sin ^{-1}\left(\frac{d s-d}{2 L_{B}}\right. \\
\theta_{1}=180-2 \beta \\
\theta_{2}=180+2 \beta\end{array}$ & $\begin{array}{l}\text { Where } \theta_{1} \text { and } \theta_{2} \text { are } \\
\text {-generator and shaft pulleys } \\
\text { contacts angles, } \\
\text { respectively. }\end{array}$ \\
\hline $\begin{array}{l}\text { Design power } \\
\left(P_{\text {des }}\right)\end{array}$ & $P_{\text {des }}=C_{\text {serv }} P_{t}$ & $\begin{array}{l}\text { Where } C_{\text {serv }} \text { is the service } \\
\text { factor. } C_{\text {serv }} \text { ranges from } 1 \\
\text { to } 1.8 \text {, depending on the } \\
\text { service conditions, such as } \\
\text { light, medium, heavy or } \\
\text { extra-heavy duty, type of } \\
\text { driver and driven } \\
\text { machinery and operational } \\
\text { hours }\end{array}$ \\
\hline $\begin{array}{l}\text { Corrected power } \\
\text { rating }\left(P_{\text {cor }}\right)\end{array}$ & $P_{\text {cor }}=P_{R} K_{\text {length }} K_{a}$ & $\begin{array}{l}\text { Where } P_{\mathrm{R}} \text { is the } \\
\text { transmission power rating; } \\
\text { and } K_{\mathrm{a}} \text { is the contact } \\
\text { factor. }\end{array}$ \\
\hline Belt speed, $V_{\text {belt }}$ & $V_{\text {belt }}=\frac{d_{G} N_{G}}{19100}$ & \\
\hline $\begin{array}{l}\text { Number of belts } \\
\left(B_{N}\right)\end{array}$ & $N_{B}=\frac{P_{\text {des }}}{P_{c o r}}$ & \\
\hline
\end{tabular}

The different types of standard V-belt sections: A, B, C, $\mathrm{D}$, and $\mathrm{E}$, deployed for various power transmission range, are presented in Table 6 . The selection of belt section depends mainly on the capacity of power being transmitted and is irrespective of the number of belts. The economic viewpoint dominates belt selection when the required power transmission falls within the overlapping zone.

Table 6: The standard V-belt sections

\begin{tabular}{|l|l|l|l|l|}
\hline Section & $\begin{array}{l}\text { Power }(\mathrm{kW}) \\
\text { range }\end{array}$ & $\begin{array}{l}\text { Minimum } \\
\text { pulley pitch } \\
\text { diameter }(\mathrm{mm})\end{array}$ & $\begin{array}{l}\text { Width } \\
(\mathrm{mm})\end{array}$ & $\begin{array}{l}\text { Thickness } \\
(\mathrm{mm})\end{array}$ \\
\hline A & $\mathbf{0 . 4 - 4}$ & $\mathbf{1 2 5}$ & $\mathbf{1 3}$ & $\mathbf{8}$ \\
\hline B & $\mathbf{1 . 5 - 1 5}$ & $\mathbf{2 0 0}$ & $\mathbf{1 7}$ & $\mathbf{1 1}$ \\
\hline C & $\mathbf{1 0 - 7 0}$ & $\mathbf{3 0 0}$ & $\mathbf{2 2}$ & $\mathbf{1 4}$ \\
\hline D & $\mathbf{3 5 - 1 5 0}$ & $\mathbf{5 0 0}$ & $\mathbf{3 2}$ & $\mathbf{1 9}$ \\
\hline E & $\mathbf{7 0 - 2 6 0}$ & $\mathbf{6 3 0}$ & $\mathbf{3 8}$ & $\mathbf{2 3}$ \\
\hline
\end{tabular}

IV.

THE PULLEY

In the technical world, a pulley is a wheel mounted on the axle or shaft, designed to transfer power between shafts linked with a cable or belt. A pulley may have a groove, such as a V-belt pulley, or without grooves for flat belts, as shown in Fig 2. Other driving elements for a pulley system are; rope, cable, and chain.

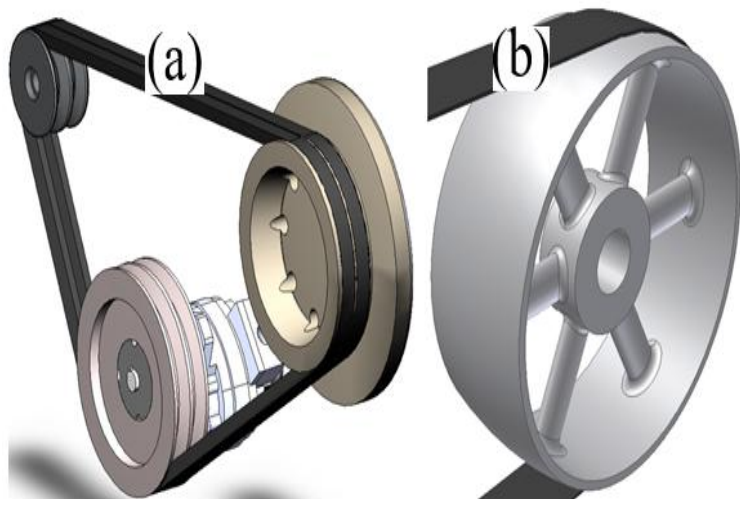

Fig 2: Pulley - (a) V-belt pulley; (b) flat belt pulley

The V-belt pulley is designed to have in-built facilities (e.g. properly machined grooves) to maximize grips on the shaft and is made from graded cast iron and mild steel. The pitch diameter (P.D) of a pulley represents the diameter of the belt as it rides in the pulley. Section D of the standard Vbelt is the most suitable for a turbine capacity of $112.4 \mathrm{~kW}$, according to Table 6 and hence, is selected for this study. The features and profile of a typical V-belt pulley corresponding to the selected V-belt are depicted in Fig 3.

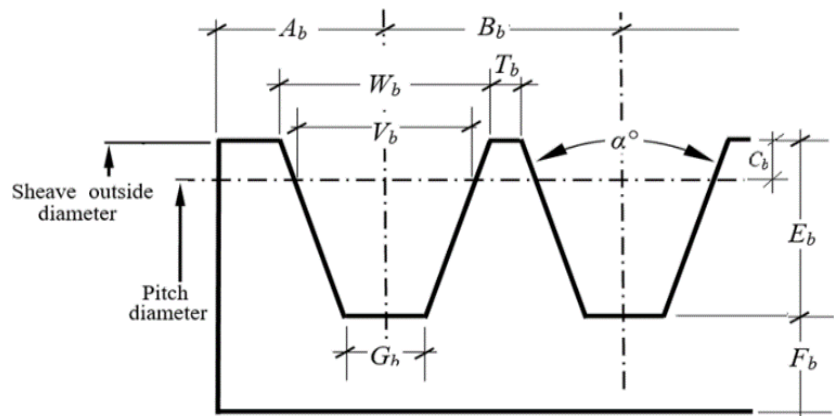

Fig 3: A profile of standard V-belt sheave grooves

The design and selection parameters of standard V-belt, section $\mathrm{D}$, are presented in Table 7.

Table 7: Standard dimensions of $D$ section V-belt sheave grooves

\begin{tabular}{|c|c|c|c|c|c|c|c|c|c|c|}
\hline $\begin{array}{l}A_{\mathrm{b}} \\
(\mathrm{mm} \\
)\end{array}$ & $\begin{array}{l}B_{\mathrm{b}} \\
(\mathrm{m} \\
\mathrm{m})\end{array}$ & $\begin{array}{l}C_{\mathrm{b}} \\
(\mathrm{mm} \\
)\end{array}$ & $\begin{array}{l}D \\
\mathrm{~b} \\
( \\
\mathrm{m} \\
\mathrm{m}\end{array}$ & $\begin{array}{l}E_{\mathrm{b}} \\
(\mathrm{m} \\
\mathrm{m})\end{array}$ & $\begin{array}{l}V_{b} \\
(\mathrm{~m} \\
\mathrm{m})\end{array}$ & $\begin{array}{l}T_{\mathrm{b}} \\
(\mathrm{m} \\
\mathrm{m})\end{array}$ & $\begin{array}{l}G_{\mathrm{b}} \\
(\mathrm{m} \\
\mathrm{m})\end{array}$ & $\begin{array}{l}W_{\mathrm{b}} \\
(\mathrm{m} \\
\mathrm{m})\end{array}$ & $\begin{array}{l}\text { Gro } \\
\text { ove } \\
\text { ang } \\
\text { le } \\
\left(\alpha^{\circ}\right)\end{array}$ & $\begin{array}{l}\text { Used } \\
\text { pitch } \\
\text { datum } \\
(\mathrm{mm})\end{array}$ \\
\hline \multirow[t]{3}{*}{3.2} & \multirow[t]{3}{*}{$\begin{array}{l}30 . \\
2\end{array}$} & \multirow[t]{3}{*}{7.6} & \multirow[t]{3}{*}{7} & \multirow[t]{3}{*}{$\begin{array}{l}26 . \\
7\end{array}$} & \multirow[t]{3}{*}{$\begin{array}{l}27 \\
.3\end{array}$} & $\begin{array}{l}4 . \\
5\end{array}$ & $\begin{array}{l}20 \\
.6\end{array}$ & $\begin{array}{l}32 . \\
0\end{array}$ & 34 & 317.5 \\
\hline & & & & & & $\begin{array}{l}4 . \\
2\end{array}$ & $\begin{array}{l}15 \\
.0\end{array}$ & $\begin{array}{l}32 . \\
3\end{array}$ & 36 & 381 \\
\hline & & & & & & $\begin{array}{l}4 . \\
0\end{array}$ & $\begin{array}{l}14 \\
.0\end{array}$ & $\begin{array}{l}32 . \\
6\end{array}$ & 38 & 508 \\
\hline
\end{tabular}

\section{DESIGN RESULTS}

The results obtained from the design calculation based on the relations and values in Tables 2 - 6 are presented in Table 7. The final values were generated using Matlab codes.

Published By:

Blue Eyes Intelligence Engineering 


\section{Simplified and Precise Design of Crossflow Turbine Power Transmission Components}

Table 7: Calculated parameters of CFT power transmission components

\begin{tabular}{|c|c|c|c|}
\hline Parameter & Value & Unit & Remarks \\
\hline \multicolumn{4}{|l|}{ Runner shaft } \\
\hline Runner speed, $N$ & 636 & rpm & \\
\hline $\begin{array}{l}\text { Maximum torque on the shaft } \\
\left(T_{\max }\right)\end{array}$ & 2.3 & $\mathrm{kN}-\mathrm{m}$ & \\
\hline Shaft diameter, $d$ & 65 & $\mathrm{~mm}$ & \\
\hline \multicolumn{4}{|l|}{ V-belt and pulley } \\
\hline Turbine shaft pulley diameter $\left(d_{s}\right)$ & 354 & $\mathrm{~mm}$ & \multirow[b]{2}{*}{ Standard value } \\
\hline Generator pulley diameter $\left(d_{\mathrm{G}}\right)$ & 150 & $\mathrm{~mm}$ & \\
\hline Belt tension $\left(T_{1}\right)$ & 488 & $\mathrm{kN}$ & \\
\hline Belt tension $\left(T_{2}\right)$ & 163 & $\mathrm{kN}$ & \\
\hline Transmission ratio $\left(R_{\mathrm{t}}\right) ; R_{\mathrm{t}} \geq 1$ & 2.36 & & \\
\hline Calculated datum length & 2591 & $\mathrm{~mm}$ & \\
\hline Standard datum length $L_{\mathrm{dLs}}$ & 2575 & $\mathrm{~mm}$ & \\
\hline Length of the belt & 1825 & $\mathrm{~mm}$ & SPB1825 \\
\hline Belt velocity & 11.7 & $\mathrm{~m} / \mathrm{s}$ & $\begin{array}{l}<40 \text { is } \\
\text { recommended }\end{array}$ \\
\hline Belt centre distance, $C_{\mathrm{d}}$ & 892 & $\mathrm{~mm}$ & \\
\hline Pulley Gap & 648 & $\mathrm{~mm}$ & \\
\hline Number of belts, $N_{\mathrm{B}}$ & 2 & pcs & \\
\hline Wrap angle $\left(\beta^{\circ}\right)$ & 2 & & \\
\hline $\begin{array}{l}\text { Generator pulley contact angle } \\
\text { (smaller) }\left(\theta_{1}\right)\end{array}$ & 176 & o & \\
\hline Shaft pulley contact angle $\left(\theta_{2}\right)$ & 186 & 0 & \\
\hline
\end{tabular}

\section{Shaft profile}

The identification of the loads on the shaft is required to determine the resultant moment and the subsequent diameter. The power transmission shaft has different sections, as shown in Fig 4.

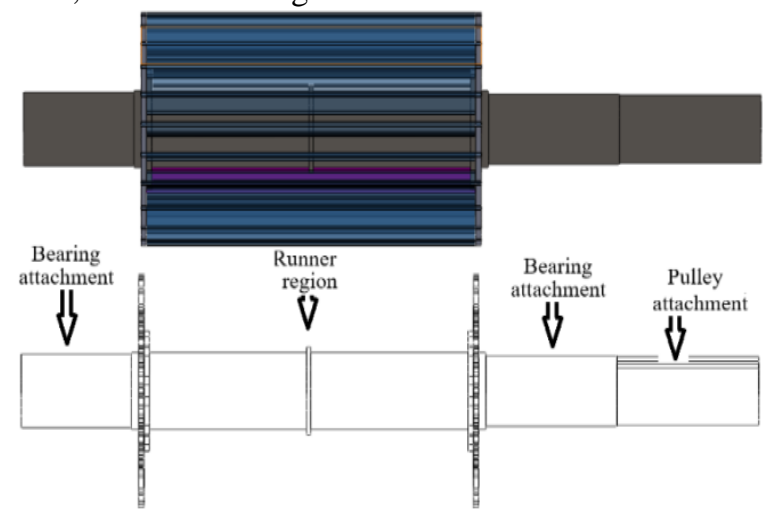

Fig 4: The different sections in the shaft

Three different diameters (40 mm, $50 \mathrm{~mm}$, and $60 \mathrm{~mm}$ ) were used based on the design computation and the set FOS to validate the integrity of the shaft. The simulation results presented in Table 8 show that:

i. $\quad$ Shaft diameter $40 \mathrm{~mm}$ has the least FOS and highest displacement and stress. This shaft failed, as indicated by the failure arrow in the von Mises legend.

ii. Shaft diameter $50 \mathrm{~mm}$ shows better results compared to the shaft of diameter $40 \mathrm{~mm}$. However, the minimum FOS is 1.6, which is smaller than the set FOS of 2.6.

iii. Shaft $65 \mathrm{~mm}$ is based on design computation and the simulation results show that it has the lowest displacement and stress, and the highest FOS of 2.6.
Table 8: Simulation results

\begin{tabular}{|c|c|c|c|c|c|c|}
\hline Limits & $\begin{array}{l}\text { Minu } \\
\text { mum }\end{array}$ & $\begin{array}{l}\text { Max } \\
\text { imu } \\
\text { m }\end{array}$ & $\begin{array}{l}\text { Minu } \\
\text { mum }\end{array}$ & $\begin{array}{l}\text { Max } \\
\text { imu } \\
\text { m }\end{array}$ & $\begin{array}{l}\text { Min } \\
\text { umu } \\
\text { m }\end{array}$ & $\begin{array}{l}\text { Maxim } \\
\text { um }\end{array}$ \\
\hline $\begin{array}{l}\text { Shaft } \\
\text { diameter } \\
(\mathrm{mm})\end{array}$ & \multicolumn{2}{|l|}{40} & \multicolumn{2}{|l|}{50} & \multicolumn{2}{|l|}{65} \\
\hline $\begin{array}{l}\text { Von } \\
\text { Mises } \\
\text { result } \\
\left(\mathrm{N} / \mathbf{m m}^{2}\right)\end{array}$ & $\begin{array}{l}5.457 x \\
10^{-7}\end{array}$ & 746 & $2.1 \times 10^{-}$ & 339 & $\begin{array}{l}3.05 \\
9 \times 10 \\
-7\end{array}$ & 205 \\
\hline $\begin{array}{l}\text { Displace } \\
\text { ment } \\
(\mathrm{mm})\end{array}$ & 0 & 0.12 & 0 & 0.09 & 0 & 0.06 \\
\hline FOS & 0.7 & $\begin{array}{l}9.7 \mathrm{x} \\
10^{8}\end{array}$ & 1.6 & $\begin{array}{l}2.5 \mathrm{x} \\
10^{9}\end{array}$ & 2.6 & $1.7 \times 10^{9}$ \\
\hline & $\begin{array}{l}\text { Sign of } \\
\text { failure }\end{array}$ & von Mises & $\begin{array}{l}\text { dy } \\
\mathbf{d}\end{array}$ & $\begin{array}{l}\mathrm{N} / \mathrm{mm}^{\wedge} 2(\mathrm{MP} \\
3.390 \mathrm{e}+02 \\
3.107 \mathrm{e}+02 \\
2.825 \mathrm{e}+02 \\
2.542 \mathrm{e}+02 \\
2.260 \mathrm{e}+02 \\
1.977 \mathrm{e}+02 \\
1.695 \mathrm{e}+02 \\
1.412 \mathrm{e}+02 \\
1.130 \mathrm{e}+02 \\
8.474 \mathrm{e}+01 \\
5.650 \mathrm{e}+01 \\
2.825 \mathrm{e}+01 \\
2.088 \mathrm{e}-07 \\
\text { rength: } 5.300 \mathrm{e}\end{array}$ & 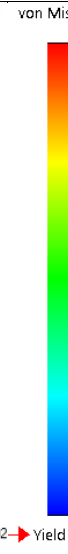 & $\begin{array}{l}(\mathrm{N} / \mathrm{mm} \wedge 2(\mathrm{MPa})) \\
2.050 \mathrm{e}+02 \\
1.879 \mathrm{e}+02 \\
1.708 \mathrm{e}+02 \\
1.538 \mathrm{e}+02 \\
1.367 \mathrm{e}+02 \\
1.196 \mathrm{e}+02 \\
1.025 \mathrm{e}+02 \\
8.542 \mathrm{e}+01 \\
6.834 \mathrm{e}+01 \\
5.125 \mathrm{e}+01 \\
3.417 \mathrm{e}+01 \\
1.708 \mathrm{e}+01 \\
3.059 \mathrm{e}-07 \\
\text { ength: } 5.300 \mathrm{e}+02\end{array}$ \\
\hline
\end{tabular}

VI.

\section{CONCLUSION}

The provision of adequate energy in SSA has been a perennial problem and efforts to change the narrative are being consumed. The issue is more challenging in the contemporary energy space where there is strong advocacy championed by the United Nations (UN) for cheap and clean energy for all by 2030. Despite the pressure caused by the above factors, the vast SHP resource in the region is still grossly untapped. Studies have attributed this scenario to a lack of SHP expertise and underdeveloped manufacturing infrastructure in the region. The design of CFT and other hydro turbines requires a careful and thorough design to ensure high efficiency and to prevent unnecessary breakdown. To bridge the capacity gap, this study identifies the CFT power transmission subsystem critical to CFT efficiency and presents a simplified and precise design process for the subsystem. The hydrological properties of the Ayiba SHP site, Nigeria, were adopted and used in this study. The simulation result, which is based on von Mises, was satisfactory, as the highest stress obtained was 205 $\mathrm{N} / \mathrm{mm}^{2}$ in the shaft and this ensued 2.6 factor of safety.

\section{REFERENCES}

1. W. S. Ebhota and F. L. Inambao, "Electricity insufficiency in Africa: A product of inadequate manufacturing capacity," African Journal of Science, Technology, Innovation and Development, vol. 8, pp. 197 204, 2016/06/10 2016 .

2. W. S. Ebhota and P. Y. Tabakov, "Hydropower Potentials and Effects of Poor Manufacturing Infrastructure on Small Hydropower Development in Sub-Saharan Africa," International Journal of Energy Economics and Policy, vol. 7 pp. 6067, 2017.

Published By:

Blue Eyes Intelligence Engineering 


\section{Simplified and Precise Design of Crossflow Turbine Power Transmission Components}

3. D. J. Obadote, "Energy Crisis in Nigeria: Technical Issues and Solutions," presented at the Power Sector Prayer Conference, Nigeria, 2009.

4. A. Korkovelos, D. Mentis, S. H. Siyal, C. Arderne, H. Rogner, M. Bazilian, et al., "A Geospatial Assessment of Small-Scale Hydropower Potential in Sub-Saharan Africa," Energies, vol. 11, p. 3100, 2018.

5. W. S. Ebhota and F. L. Inambao, "Design Basics of a Small Hydro Turbine Plant for Capacity Building in sub-Saharan Africa " African Journal of Science, Technology, Innovation and Development, vol. 8, pp. 111-120, 2016.

6. W. S. Ebhota and F. L. Inambao, "Facilitating Greater Energy Access in Rural and Remote Areas of Sub-Saharan Africa: Small Hydropower," Energy \& Environment, vol. 28, pp. 316-329, 2017.

7. W. S. Ebhota and F. L. Inambao, "Smart Design and Development of a Small Hydropower System and Exploitation of Locally Sourced Material for Pelton Turbine Bucket Production," Iranian Journal of Science and Technology, Transactions of Mechanical Engineering, vol. 43, pp. 291-314, 2019/06/01 2019.

8. C. S. Kaunda, C. Z. Kimambo, and T. K. Nielsen, "Potential of SmallScale Hydropower for Electricity Generation in Sub-Saharan Africa," ISRN Renewable Energy, vol. 2012, p. 132606, 2012/08/28 2012.

9. P. Oliver, "Small Hydro Power: Technology and Current Status. Renewable and Sustainable," Energy Reviews, vol. 6 pp. 537-556, 2002.

10. S. Singal, "Planning and Implementation of Small Hydropower (SHP) Projects," Hydro Nepal, vol. 5, 2009.

11. SPLASH, "Guidelines for Micro Hydropower Development," Spatial Plans and Local Arrangement for Small Hydro.

12. UNIDO, "World Small Hydropower Development Report 2013," United Nations Industrial Development Organization and International Center on Small Hydro Power, 2013.

13. IRENA, "Renewable Power Generation Costs in 2014," International Renewable Energy Agency (IRENA), 2014

14. E. Arthur, F. O. K. Anyemedu, C. Gyamfi, P. Asantewaa - Tannor, K. A. Adjei, G. K. Anornu, et al., "Potential for small hydropower development in the Lower Pra River Basin, Ghana," Journal of Hydrology: Regional Studies, vol. 32, p. 100757, 2020/12/01/ 2020.

15. A. P. Hurford, J. J. Harou, L. Bonzanigo, P. A. Ray, P. Karki, L. Bharati, et al., "Efficient and robust hydropower system design under uncertainty - A demonstration in Nepal," Renewable and Sustainable Energy Reviews, vol. 132, p. 109910, 2020/10/01/ 2020.

16. C. Zhang, S. Chen, H. Qiao, L. Dong, Z. Huang, and C. Ou, "Small hydropower sustainability evaluation for the countries along the Belt and Road," Environmental Development, vol. 34, p. 100528, 2020/06/01/ 2020.

17. I. A. Adejumobi, A. A. Esan, and A. B. Okunuga, "Discovering Potential Sites for Small Hydro Power (SHP) in Nigeria," Advanced Materials Research, vol. 18-19, pp. 93-97, 2007.

18. W. S. Ebhota, "Simplified framework for Small Hydropower Potential Site Development and the Determination of Turbine Capacity," International Journal of Applied Engineering Research vol. 13, pp. 15530-15538, 2018.

19. Z. U. O. Shilun, Z. Xiong, and Z. Gang, "Comprehensive welding technology for type 304 stainless steel rotating shaft," Procedia Engineering, vol. 24, pp. 840-844, 2011/01/01/ 2011. domestic

20. M. F. McGuire. (2008). Stainless Steels for Design Engineers.

21. ASM. (2000). Alloy Digest Sourcebook: Stainless Steels. Available: https://www.asminternational.org/search/-

/journal_content/56/10192/06940G/PUBLICATION\#tabs

\section{AUTHORS PROFILE}

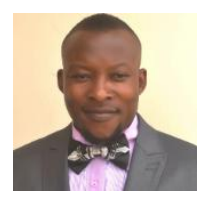

Dr. Williams S. Ebhota holds $\mathrm{PhD}$, Master, and Bachelor degrees in mechanical engineering, obtained from University of Kwazulu-Natal, Nnamdi Azikiwe University, and Ambrose Alli University, respectively. He has authored several research papers and his research cuts across manufacturing, design, and renewable energy studies.

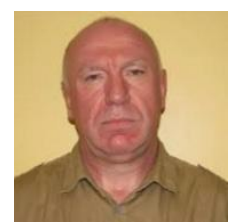

Co Author: Professor PY Tabakov holds a Master of Science (MSc) degree in Civil Engineering from Kyiv Civil Engineering Institute, Ukraine and Doctor of Philosophy (PhD) in Mechanical Engineering with specialization in composite materials and solid mechanics from the University of KwaZulu-Natal, South Africa. Currently, he is a Full

Published By: of Technology, South Africa. His research interest includes such fields as solid mechanics, composite materials, evolutionary optimization, energy, artificial intelligence, and data mining. 